California State University, Monterey Bay

Digital Commons@ @ CSUMB

\title{
1970 - Geology of Southern Monterey Bay and Its Relationship to the Groundwater Basin and Salt Water Intrusion
}

Follow this and additional works at: https://digitalcommons.csumb.edu/hornbeck_cgb_1

Part of the Business Commons, Education Commons, Engineering Commons, Life Sciences Commons, and the Social and Behavioral Sciences Commons

\section{Recommended Citation}

"1970 - Geology of Southern Monterey Bay and Its Relationship to the Groundwater Basin and Salt Water Intrusion" (2018). State and Federal Documents Relating to Monterey and San Luis Obispo Counties. 18. https://digitalcommons.csumb.edu/hornbeck_cgb_1/18

This Report is brought to you for free and open access by the Salinas River and Carmel River Groundwater Basins at Digital Commons @ CSUMB. It has been accepted for inclusion in State and Federal Documents Relating to Monterey and San Luis Obispo Counties by an authorized administrator of Digital Commons @ CSUMB. For more information, please contact digitalcommons@csumb.edu. 
(200:

- R29=

\section{UNITED STATES DEPARTMENT OF THE INTERIOR}

GEOLOGICAL SURVEY

\section{GEOLOGY OF SOUTHERN MONTEREY BAY AND ITS RELATIONSHIP \\ TO THE GROUND WATER BASIN AND SALT WATER INTRUSION}

By

H. Gary Greene

In cooperation with California State

Department of Water Resources

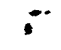

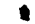

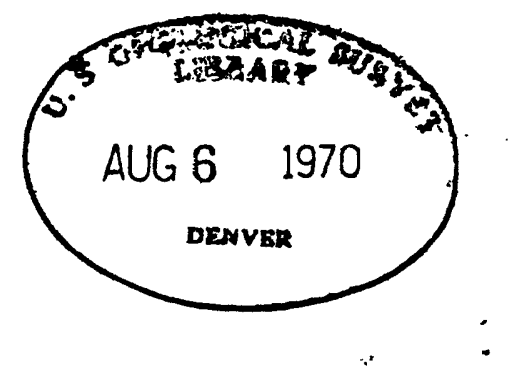

Open-file report

$$
\begin{array}{r}
1970 \\
70-141
\end{array}
$$

This report is preliminary and has not been edited or reviewed for conformity with Geological Survey standards 
GEOLOGY OF SOUTHERN MONTEREY BAY AND ITS RELATIONSHIP TO

THE GROUND WATER BASIN AND SALT WATER INTRUSION

by

\section{H. Gary Greene}

\section{INTRODUCTION}

Knowledge of subsurface geology in the nearshore portion of Monterey Bay is desirable for the understanding of the sea water intrusion problem that exist in the lower Salinas Valley. Since the early 1940's continuous heavy pumping along the coastal area of the Salinas Valley has depleted the ground water storage and lowered the piezometric levels to an elevation that encourages sea water encroachment and has caused degradation of the ground water quality.

Ground water accounts for more than $95 \%$ of the water used in the Salinas Valley. Increasing demand for high quality water for agricultural, domestic, and municipality uses have made the search for a solution to the sea water encroachment problem a major critical objective in all county and state water resources agencies connected with the Salinas Valley ground water basin.

A natural westward-sloping ground water gradient in the Salinas Valley extends from the upper portion of the valley to Monterey Bay. During periods of heavy summer pumping, a water level depression, created by the formation of a pumping trough, reverses the hydraulic gradient and salt water enters through the subsurface from beneath 
Monterey Bay. The entrance of salt water into the fresh water aquifers is thought to take place along the walls and bottom of Monterey Submarine Canyon where lithologic units that contain these aquifers crop out. Calffornla State Department of Water Resources (in press) study of the Monterey Bay area assumes a direct hydraulic connection of unknown magnitude with water bearing strata and the salt water of Monterey Bay. The report presumes Monterey Submarine Canyon and its tributary canyons to be the main source areas for sea water intrusion. The head of the Monterey Submarine Canyon appears to have been cut into alluvium deposited by the Salinas River and adjacent streams. This assumption by the State of California, Department of Water Resources, is based principally on a gravelly outcrop known to exist in the canyon walls and thought to represent the seaward extension of the "180-foot" (55 meters) aquifer (California State Department of Water Resources, 1958).

This report discusses preliminary results of a U.S. Geological Survey - State of California joint investigation of Monterey Bay. The objective of the Monterey Bay survey is to delineate the ground water basin offshore, to determine the distribution and locations of fresh water aquifers, or in other words, to locate areas in Monterey Submarine Canyon and on the ocean bottom in Monterey Bay where aquifers may outcrop and thus be areas of entrance for sea water. 
The area of Investigation is located in Monterey Bay, California, which lies between the towns of Santa Cruz and Monterey, or between latitudes $36^{\circ} 35^{\prime} \mathrm{N}$ and $37^{\circ} 00^{\prime} \mathrm{N}$ and longitudes $121^{\circ} 10^{\prime} \mathrm{W}$ and $121^{\circ} 45^{\prime} \mathrm{W}$ (Fig. 1). The investigation reported here discusses the results of the survey made in the southern portion of Monterey Bay only (Fig. 1). Results of the remaining portion of the survey will be discussed in a later report.

Previous Investigations

A considerable amount of oceanographic work has been done in Monterey Bay, however, the list is too lengthy and unrelated to the present investigation to enumerate here. To my knowledge, this is the first extensive and detailed geophysical survey of Monterey Bay. Shepard (1948) Martin (1964) and Martin and Emery (1967) have made geologic Investigations of Monterey Bay; these were mostly associated with the Monterey Submarine Canyon. Curray (1966) has run reconnaissance seismic lines into Monterey Bay but these were related to larger investigations of the continental shelf off central California.

Offshore geology has been reported by Martin (1964) and Martin and Emery (1967) and the following brief description has been obtained from these two papers. Martin's conclusions are supported by data he obtained in Monterey Bay in 1961 and 1962. This data consist of continuous acoustical profiles (fathometer records), rock dredges from side walls of Monterey Canyon, and grab samples and cores gathered from the floor of Monterey Bay. 


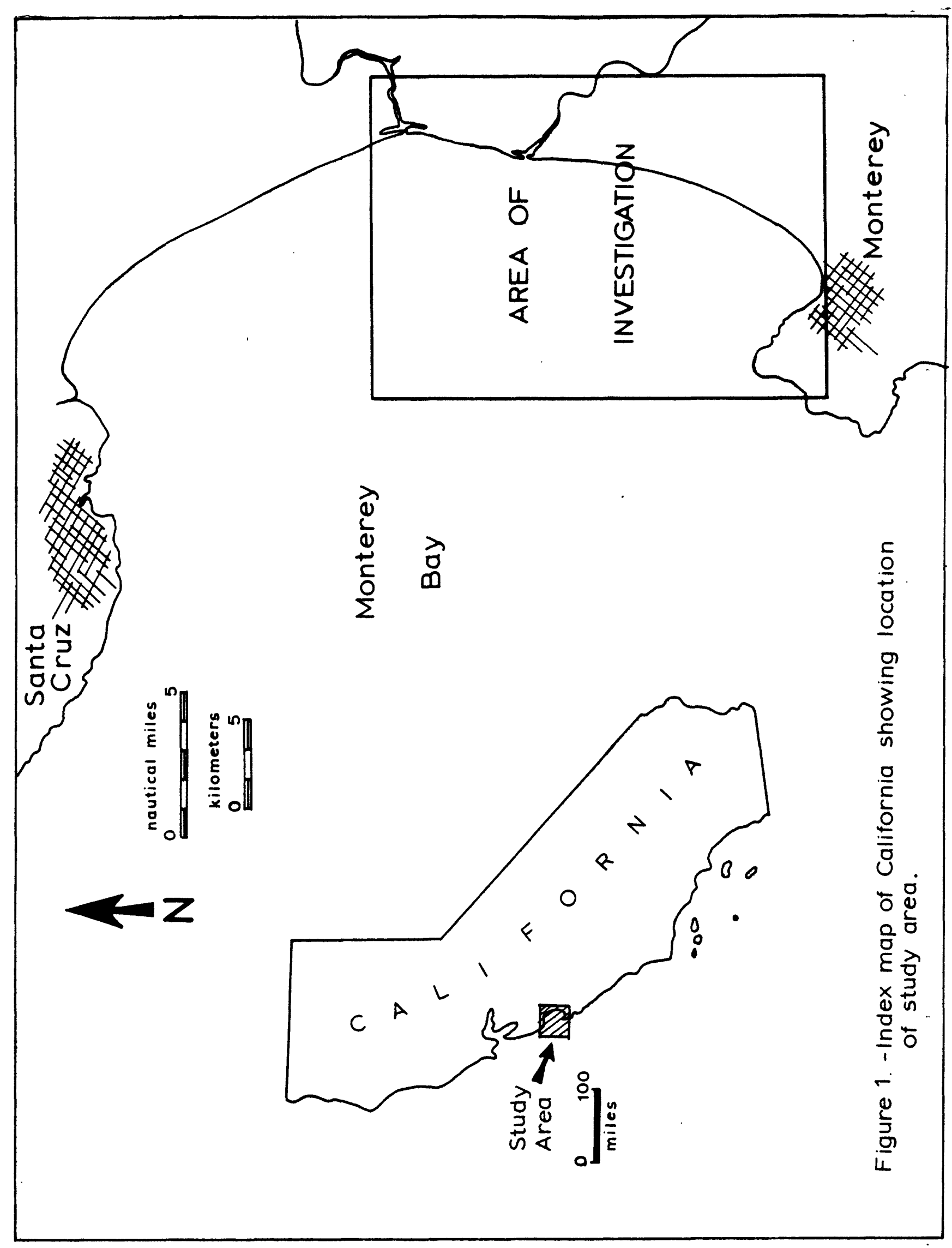


Martin (1.967, p. 2289) reports that much of the south side of Monterey Canyon consists of granodiorite and on the opposite wall (north side) lie upper Pliocene sedimentary strata; these two units are separated by a fault running down the canyon axis (Fig. 2). The Pliocene strata correlate with the Pompanio Member of the Purisima Formation in the Santa Cruz Mountains and the granodiorite correlates with the lower Upper Cretaceous Santa Lucia granodiorite onshore. Only in one locality, in the most southerly portion of Monterey Bay, does Miocene strata outcrop. The remainder of the bay and canyon area is covered with Holocene sand, green mud, and sandy green mud that today are being actively reworked by bottom currents. On land, Woodford (1951) and Starke and Howard (1968) have investigated the landward extension of the Monterey Submarine Canyon. Johnson (1855) Clark (1930) Woodring (1938) Taliaferro (1943) Allen (1946) Baldwin (1963) Manning (1963) Bowin (unpublished) and California State Department of Water Resources (in press) have all contributed to the geology of the lower Salinas Valley and the onshore area surrounding Monterey Bay.

The study of salt water intrusion in this area began in 1931 when salt water was first discovered in wells located along the shores of Monterey Bay. Since that time the State of California, Department of Water Resources, and the counties of Santa Cruz and Monterey have been cooperating in the study of salt water intrusion. Prior to the present study, however no offshore investigation related to the distribution of fresh water aquifers has been conducted. 


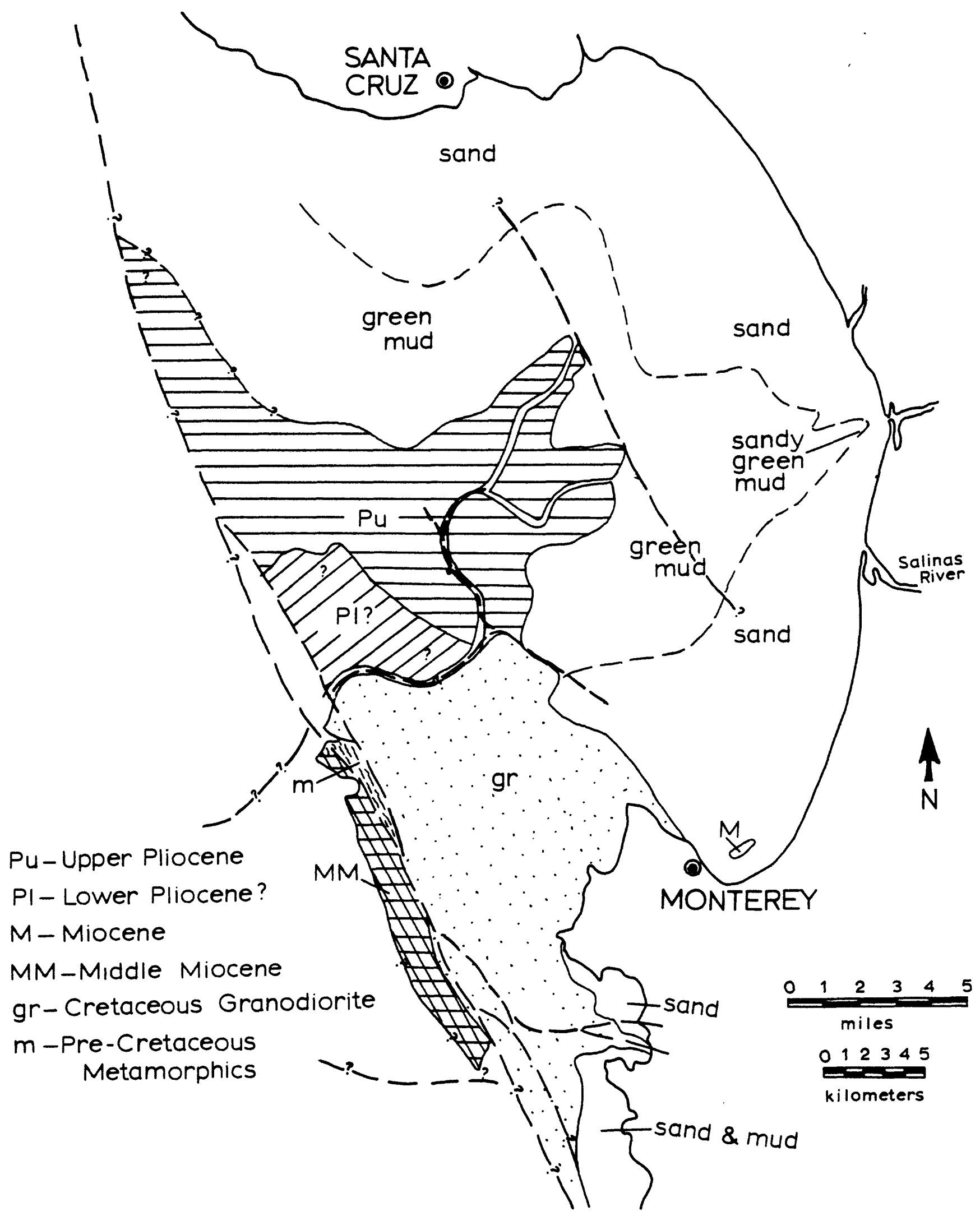

Figure 2.- Geologic map based on samples from sea floor and extrapolation from outcrops on shore. (After Martin, 1967). 


\section{GEOLOGIC SETTING}

The following discussion of onshore geology is brief and for the most part has been taken from the geologic map of the California State Department of Water Resources (in press).

The distribution of geologic units adjacent to the southern portion of Monterey Bay is shown in Plate 1. These units include Mesozoic granodiorite $(\mathrm{Gr})$, Miocene marine siltstones of the Monterey Formation (Tm), upper Pliocene to Pleistocene alluvial fan deposits of the Paso Robles Formation ( $Q p r)$, Pleistocene brown and red sands of the Aromas red sands unit (Qpa), Pleistocene to Holocene sand dune deposits of the Older sand dunes unit (Qod), Pleistocene to Holocene alluvium of the Older alluvium unit (Qoal), Holocene Floodplain deposits (Qf1), Holocene alluvium of the Intermediate Alluvium unit (Qa1), and Younger alluvium unit (Qya1), Holocene basin deposits ( $Q b)$, Holocene Stream channel deposits (Qsc), and Holocene sand dunes of the Recent sand dunes unit (Qsd) (California State Department of Water Resources, in press).

California State Department of Water Resources (in press) has used the term "Valleyfill Materials" for all post-Aromas sediments, which consist of marine and valley terraces, older, intermediate, and younger alluvium, alluvial fan deposits, floodplain deposits, basin deposits, older and recent sand dunes and stream deposits. In this report Valleyfill material will be treated as a lithologic unit without separation of its constituent parts and no further mention of 
of these constituents will be made.

Nonwater-bearing rocks

The nonwater-bearing rocks consist of the Mesozoic granodiorite and Miocene and older marine sediments.

1. Mesozoic granodiorite -- The granitic rocks that outcrop around Point Pinos near Monterey have been identified as a granodiorite belonging to the Sur Series and probably of late Cretaceous age (Martin, 1967, p. 2289). This unit is highly fractured and contains large phenocryst of $\mathrm{K}$-feldspar.

2. Monterey Formation -- The Miocene marine unit is called the Monterey Formation and is a resistant brown, siliclous mudstone interbedded with lenticular beds of opaline chert. In this area the Monterey Formation, which is of varying thickness, rest upon the irregular surface of the granodiorite (Bramlette, 1946, p. 5). According to Bramlette (1946, p. 5) an upper member (unnamed) consisting mainly of diatomite and diatomaceous shale grades transitionally into a lower member that consists mainly of porcelaneous shale that is difficult to subdivide into mappable units. Stratigraphic position of isolated beds were correlated on the basis of foraminiferal zones only.

Water-bearing materials

Water-bearing materials reported by the California State Department of Water Resources (In press) consist of the Pliocene marine unit known as the Purisima Formation, the Pliocene Paso Robles Formation, the 
Pleistocene Aromas red sands and the Holocene Valleyfill materials.

1. Purisima Formation -- The Pliocene marine unit is called the Purisima Formation and consist of mostly poorly indurated gravels, sands, silts, and silty clay that may total 3050 meters $(10,000$ feet) thick. The Purisima overlies older marine sediments and is overlain by the Aromas red sands and Valleyfill material. This formation is exposed only in the northern portion of the Pajaro Valley area and is mentioned here because $1 t$ is found in the subsurface.

2. Paso Robles Formation -- The Paso Robles Formation of upper Pliocene to Pleistocene age consists of sand, gravel and clay that is interbedded with some minor calcareous beds and has a total thickness of about 760 meters (2500 feet). This formation includes alluvial fan, lake, and floodplain deposits and probably locally contains the "400-foot" (122 meters) aquifer.

3. Aromas red sands -- The Aromas red sands of Pleistocene age consist of well sorted, friable, quartzose, brown to red sand that in some localities is interbedded with a thin basal breccia member. The Aromas red sands has a total thickness of about 305 meters (1000 feet) and unconformably overlies older units. Aromas red sands are thought to have been deposited in a lagoonal or shoreline environment where both wind and waves acted as a depositional agent and probably locally contains the "400-foot" (122 meters) aquifer.

4. Valleyfill Material -- Valleyfill material of Pleistocene to Holocene age consist mainly of unconsolidated sediments of gravel, sand, 
silt and clay that have been deposited as alluvium, floodplain deposits, bay deposits, marine and valley terrace deposits, and sand dune deposits. Valleyfill material has a maximum thickness of 305 meters (1000 feet) and rests unconformably on marine sediments. The valleyfill materials include aquifers of sand and sandy gravels and aquicludes of clay and silty clay. The "180-foot" (55 meters) aquifer occurs in the Valleyfill material.

Onshore, in the central portion of Monterey Bay, at Moss Landing, Woodford (1951) and Stark and Howard (1968) have reported the presence of a buried canyon or gorge believed to be either the ancestral Monterey Canyon or the Pajaro Gorge. This interpretation resulted from drill-hole data. One well indicated granite (granodiorite) as being deeper than 2290 meters (7500 feet).

\section{Geologic Structure}

The geologic structure of the Monterey Bay region consist mainly of faults. Distribution and trend of faults adjacent to Monterey Bay are illustrated in Figure 3, major faults are labeled. Two major faults have been mapped in the southern Monterey Bay-Salinas Valley areas; the Gabilan and Tularcitos faults (Plate 1). These faults are nearly parallel to each other and at their extreme southern ends they appear to extend out to Monterey Bay under the Valleyfill material.

1. Gabilan fault -- The Gabilan fault is associated with the Salinas flexure, or Gabilan Escarpment (Martin, 1964, p. 106), 


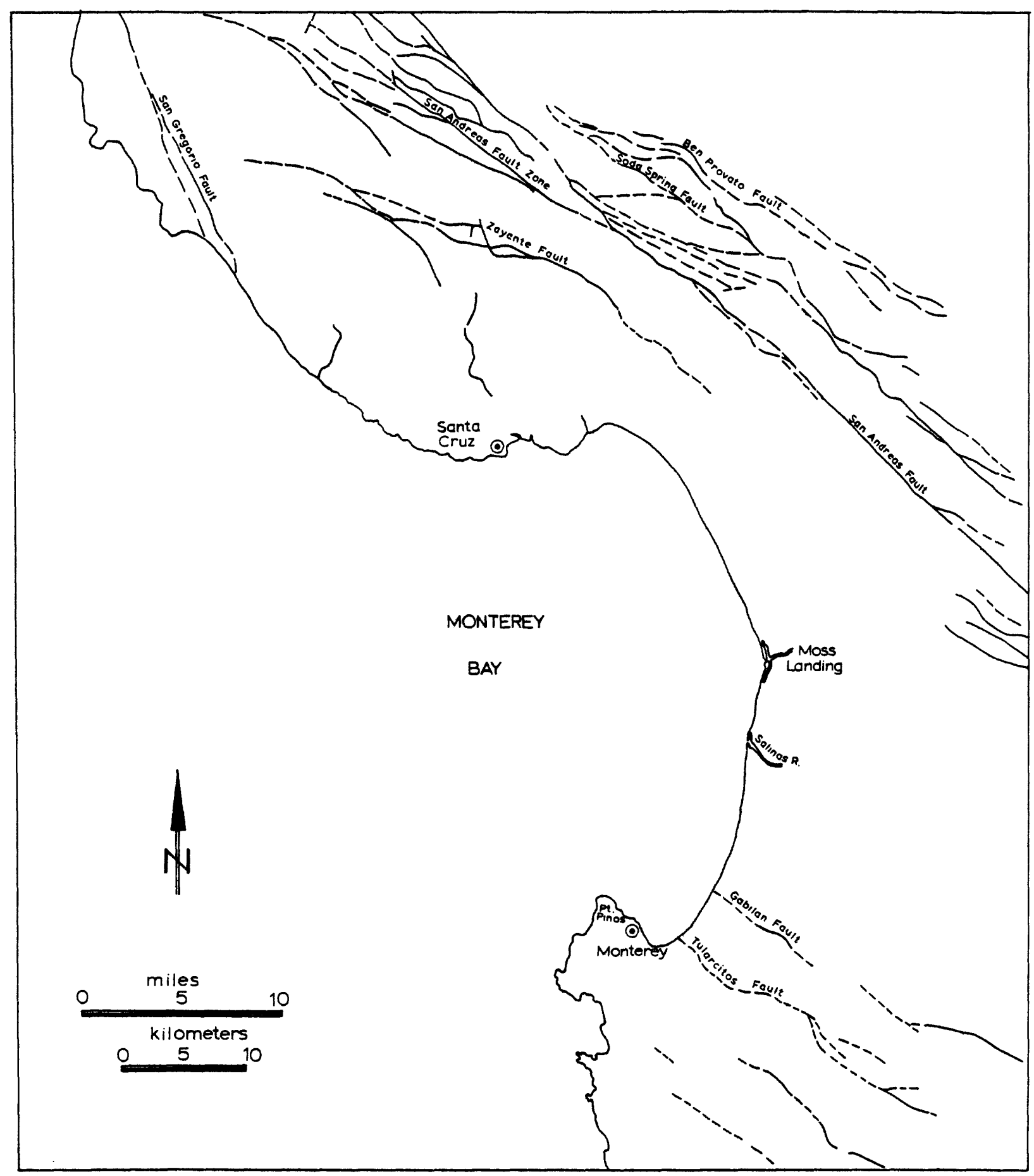

Figure 3.-- Map showing distribution and trend of faults adjacent to Monterey Bay. Major faults are labeled. (After State of Calif. Division of Mines and Geology Geologic Map of Calif., San Francisco, San Jose, and Santa Cruz sheets). 
which together make-up a major structural feature that runs along the west side of Salinas Valley. The fault seems to have had a vertical sense of movement with the east side dropped down. This has brought the Miocene marine sediments of the Monterey Formation on the west side of the fault into juxtaposition with the PlioPleistocene alluvial deposits of the Paso Robles Formation on the east side of the fault (California State Department of Water Resources, in press).

2. Tularcitos fault -- The Tularcitos fault is roughly parallel to the Gabilan fault and has the same sense of movement. It has a vertical displacement with the east side down dropped (California State Department of Water Resources, in press).

Martin (1964, p. 105) suggests the existence of two faults in the southern portion of Monterey Bay; the Gabilan and Monterey faults (Fig. 2). The Gabilan fault was inferred between the Ben Lomond high and the San Gregoriel fault and in the bay it is located just east of the upper Pliocene outcrops in Monterey Canyon, approximately $12 \mathrm{~km}$ (6 naut. miles) from shore. Martin and Emery (1967, p. 2290) have suggested approximately 305 meters (1000 feet) downdrop on the eastern side of the fault. The Monterey fault is located in Monterey Canyon and is suggested to separate the Upper Pliocene rocks to the north from the granodiorites to the south. Martin and Emery (1967, p. 2290) proposed a left-lateral offset of unknown displacement for the Monterey fault. 
Ground Water Basin

The ground water basin of the lower Salinas Valley consist of two main water-bearing zones separated by an aquiclude. The two zones are called the "180-foot" (55 meters) and "400-foot" (122 meters) aquifers and they consist of lenses of permeable strata that in general exhibit hydraulic continuity. These aquifers are contained in the semiconsolidated to unconsolidated material of Pleistocene to Holocene age respectively. The aquifers are generally contained within specific lithologic units and follow the overall structure of the formation in which they occur.

\section{"180-foot" aquifer}

The "180-foot". (55 meters) aquifer underlies the Salinas aquiclude and lies at an approximate depth of 15 to 76 meters (50-250 feet) and has a thickness of 15 to 46 meters (50-150 feet) (California State Department of Water Resources, in press). This aquifer is lenticular and apparently is a stream channel deposit laid down by the ancestral Salinas River (Manning, 1963). It also may be correlated stratigraphically with the older portion of the Valleyfill materials and the upper part of the Aromas red sands (California State Department of Water Resources, in press).

"400-foot" aquifer

Separating the"180-foot" (55 meters) and the "400-foot" (122 meters) aquifers is 3 to 20 meters (10-70 feet) of discontinuous aquifers and aquicludes that lie at about 82 meters (270 feet) deep. 
Beneath this zone lies the "400-foot" (122 meters) aquifer that consist of several permeable zones separated by beds of clay. This aquifer lies at a depth of 82 to 143 meters (270-470 feet) and varies in thickness from 7.5 to 60 meters (25-200 feet) (California State Department of Water Resources, in press). The "400-foot" (122 meters) aquifer is probably contained within the Paso Robles Formation and/or Aromas red sands and probably crops out offshore in Monterey Canyon. The age of the aquifer material is probably middle Pleistocene (Manning, 1963). 


$$
\text { EQUIPMENT, PROCEDURES, AND METHODS }
$$

High resolution and deep penetration seismic profiling systems mounted aboara the U.S. Geological Survey's R/V POLARIS was used to obtain the seismic data. Other equipment used during the survey consisted of a Varian proton precision magnetometer, to obtain magnetic profiles, and a precision depth recorder, to gather accurate bathymetric data.

High Resolution System

The high resolution system used a newly designed sound source, developed by the USGS, of the sparker type with electrical storage capacitors discharging a total of 600 joules of energy through a multi-point electrode. The electrode consists of a solid-wire coaxial cable perforated with 50 or more smaller wires to produce 50 or more points of emanation for the electrical arcs. Surrounding the electrodes is a cylinder of wire mesh about $15 \mathrm{~cm}$ ( 6 inches) in diameter that acts as a ground. At the instant of discharge electrical arcs travel from the electrodes to the wire mesh cylinder to produce a seismic sound source with a fundamental frequency of $1000 \mathrm{~Hz}$. A 6meter (20 foot), non-preamplified hydrophone cable with 11 crystal elements spaced about 0.6 meter ( 2 feet) apart was used to recover returning seismic energy. The sound source was towed 3 meters (10 feet) behind the survey vessel at a depth of about 0.6 meter ( 2 foot) beneath the water surface, and the first element of the hydrophone streamer was towed 33.5 meters (110 feet) behind the 
survey vessel at a depth of 1.5 meters ( 5 feet); this gave an in line separation of 30.5 meters (100 feet) between sound source and the first element of the hydrophone cable (Fig. 4).

The recovered signal was filtered and then amplified. Frequencies recorded were generally between 250 and $645 \mathrm{~Hz}$. The seismic data was graphically recorded on a Gifft seismic recorder at a 0.25 second sweep rate and a 0.75 second fire rate.

Deep Penetration System

The deep penetration system uses four 3-electrode sparker cages towed in a planar multiple-unit directional array which utilized the beam-forming technique described by Rusnak (1967, p. C85). Electrode arrangement used in this survey were identical to that discussed by Rusnak (1967, p. C84); see Figure 4 for electrode and hydrophone pattern used during the survey. A fundamental frequency of about $85 \mathrm{~Hz}$ is generated by the discharge of electrical energy from storage capacitors. Between 8000 and 12,000 joules of energy was used to obtain the deep penetrating seismic profiles. A 61-meter (200 foot) active section, preamplified hydrophone cable with 100 crystal elements spaced approximately 6 meters (20 feet) apart was used to recover returning seismic energy. The hydrophone streamer was towed between 61 and 76 meters (200-250 feet) behind the survey vessel, and about the same distance from the seismic source. Both sound source and hydrophone streamer were towed at an approximate depth of 4.5 meters ( 15 feet) beneath the water surface. 

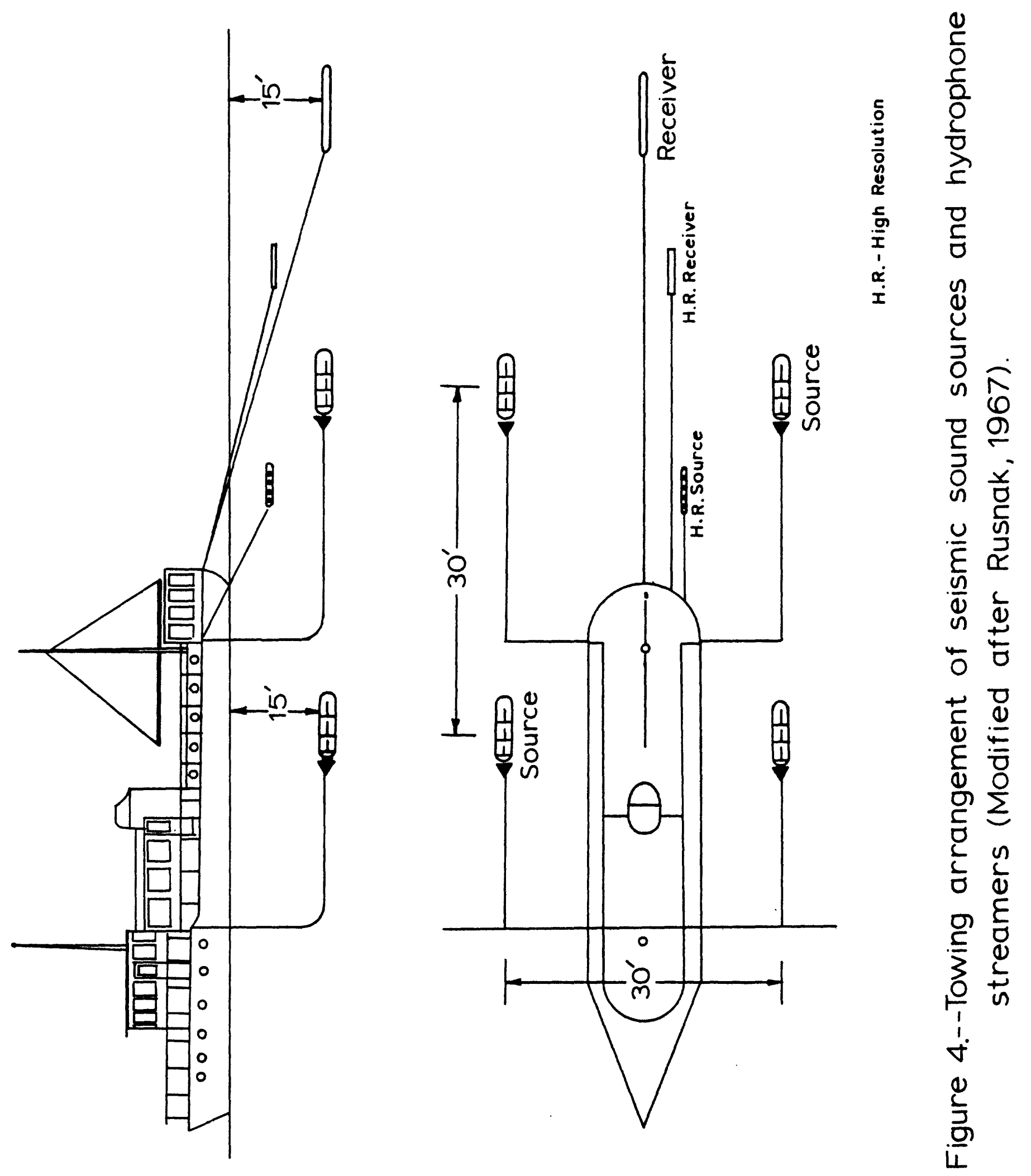
The recovered seismic signal was filtered and then amplified. Frequencies recorded were between 40 and $125 \mathrm{~Hz}$. The seismic data was graphically recorded on a Gifft seismic recorder at a 1.0 second sweep rate and a 3.0 second fire rate.

The magnetic profiles have not yet been interpreted and will not be mentioned in this report. Bathymetric data obtained during the survey has been reduced and a detailed bathymetric map and physiographic diagram of Monterey Bay has been constructed from the results (Plates 4 and 5 respectively).

Navigation

A modified anti-aircraft radar artillery director system was used for precision navigation. This radar system, mounted in a mobile van, was placed on a 18 meter (60 foot) high hill near Moss Landing where it could direct the movement of the survey vessel. A high accuracy, narrow beam radar signal producing antenna would lock onto the survey vessel and track it throughout a $38 \mathrm{~km}$ (20 naut. miles) radius. Movement of the vessel was monitored and recorded by an $X-Y$ plotting system within the van. By placing a 1:50,000 scale mapped representation of the survey grid lines on the X-Y plotter, personnel operating the radar system could give directions in the form of course and speed changes to the survey vessel and keep it tracking along a certain grid line. This system was very successful and gave an accuracy of \pm 15 meters ( \pm 50 feet). 
Seismic profiles were obtained along approximately $1600 \mathrm{~km}$ (800 naut. miles) of track (Fig. 5). The track lines were oriented northwest by southeast and northeast by southwest, forming a $2 \mathrm{~km}$ (1 mile) grid spacing. Method

Subbottom reflectors were picked from the seismic profiles and criteria was established to correlate reflectors with lithologic units. Onshore well-hole logs were used to extrapolate onshore subsurface geologic data offshore to establish a correlation with the offshore seismic data. Seismic and well-hole data usually correlated quite well. The interpretation of the seismic records resulted in establishing zones in the profiles distinguishable by differing seismic characteristics. These zones were correlated with known onshore geology and the resultant interpretation was used to construct a marine geologic map (Plate 1 ). Also, from the seismic profiles two isopach maps were constructed; one shows total thickness of the Deltaic deposits off the mouth of the Salinas River (P1ate 2) and the other shows total thickness of both the Deltaic deposits and the underlying Paso Robles Formation and/or Aromas red sands unit (Plate 3).

Line drawings and geologic interpretive cross sections of seismic profiles are used in this report to illustrate interpretation of the seismic records. Several of these illustrations also include a photograph of the seismic profile in orcier to show the interpretive 


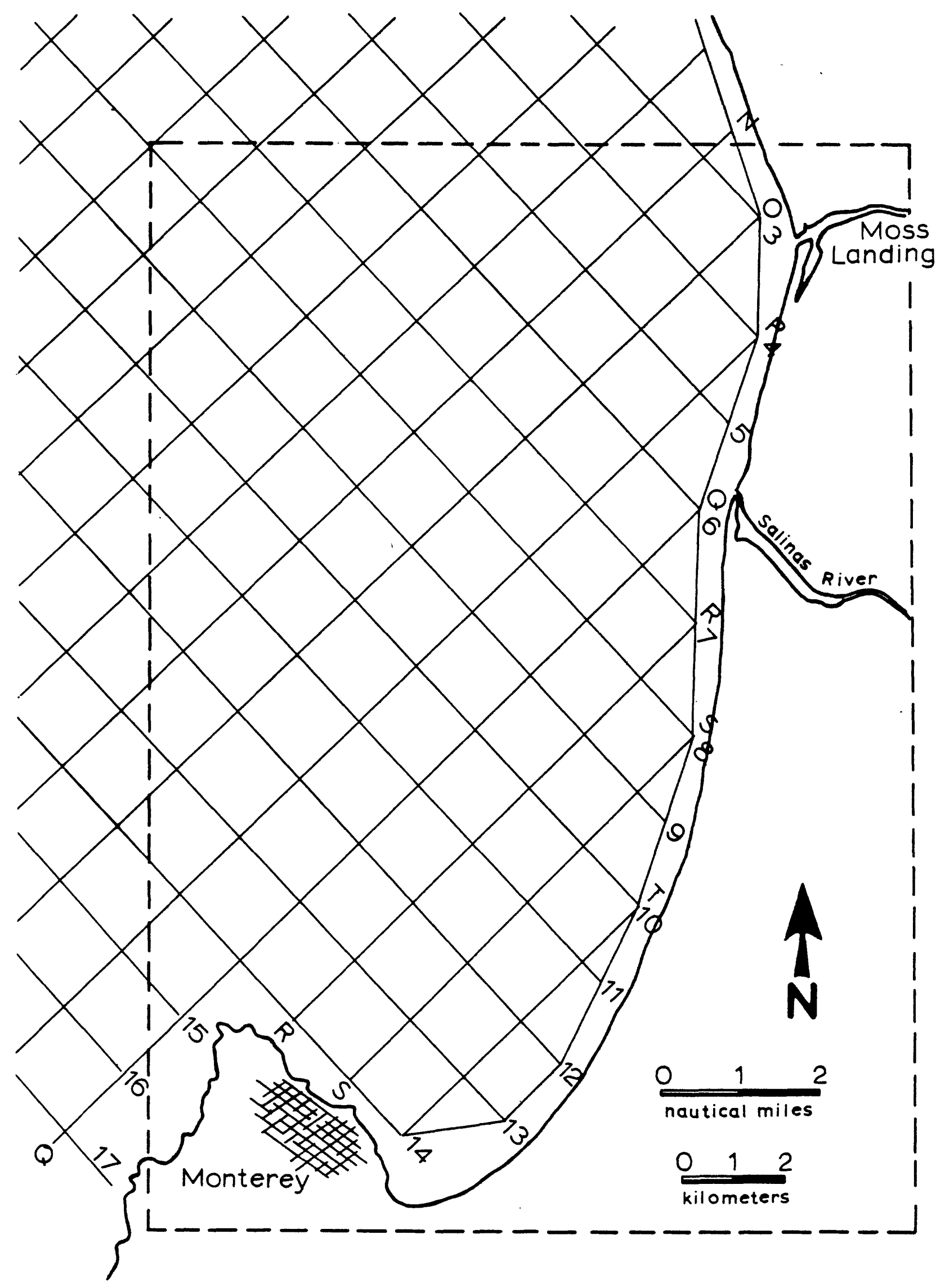

Figure 5.-Map of investigation area showing seismic profile track lines. 
progression -- from raw data to geologic cross section -- that takes place in interpretation of seismic records (Fig. 6 and 7). A line drawing is essentially a refined or, if you like, an optically filtered hand drawn representation of the seismic profile with added geological blas. Most all of the upper 150 meters (500 feet) illustrated in the geologic cross sections were interpreted from high resolution profiles. Since most of the profiles illustrated in this report have been constructed from deep penetration seismic records the upper portion of the seismic profiles and line drawings may not show clearly the same thing that is represented in the geologic cross section, this is because the "bubble-pulse" of the deep penetration records mask approximately the first 60 meters (200 feet) or more of profile beneath the ocean bottom.

Depths of reflectors were calculated using average seismic velocities of $1.5 \mathrm{~km} / \mathrm{sec}(4800 \mathrm{fps}$ ) in water, $2.0 \mathrm{~km} / \mathrm{sec}$ ( $6400 \mathrm{fps}$ ) for the unconsolidated to semiconsolidated materials existing in the top 150 meters (500 feet) of section, and $2.5 \mathrm{~km} / \mathrm{sec}$ ( $8000 \mathrm{fps}$ ) for consolidated sediments below 150 meters (500 feet) and overlying basement. No corrections for changes in sea level (tides, etc.) during the survey were made.

Apparent dips of recognizable sedimentary beds observed in the selsmic profiles were plotted. Since the interpretations of all track lines were perpendicular to each other, true dips could be determined with a stereo-net. 


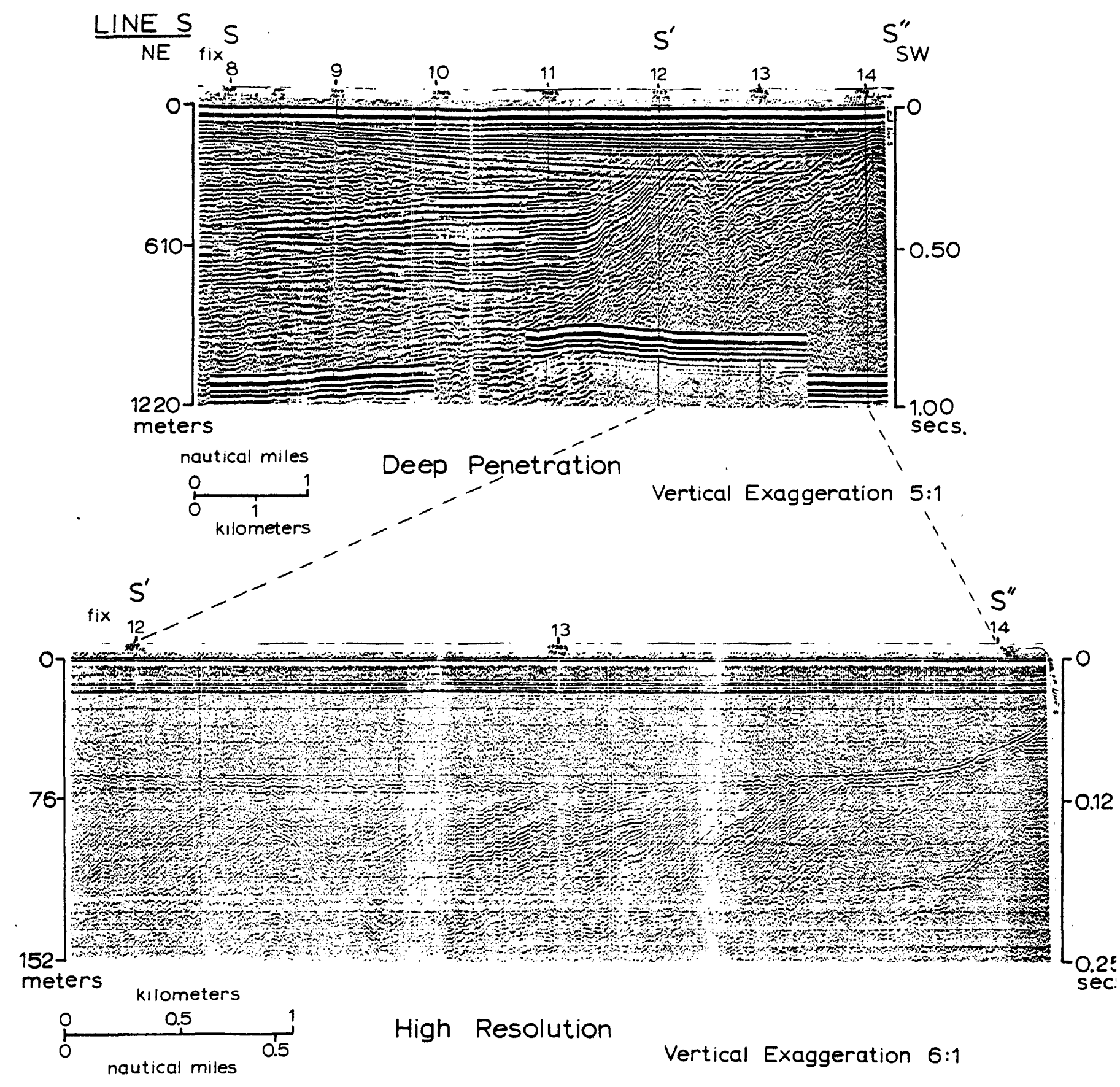

Figure 6.-Deep penetration and high resolution seismic profiles of line S. 

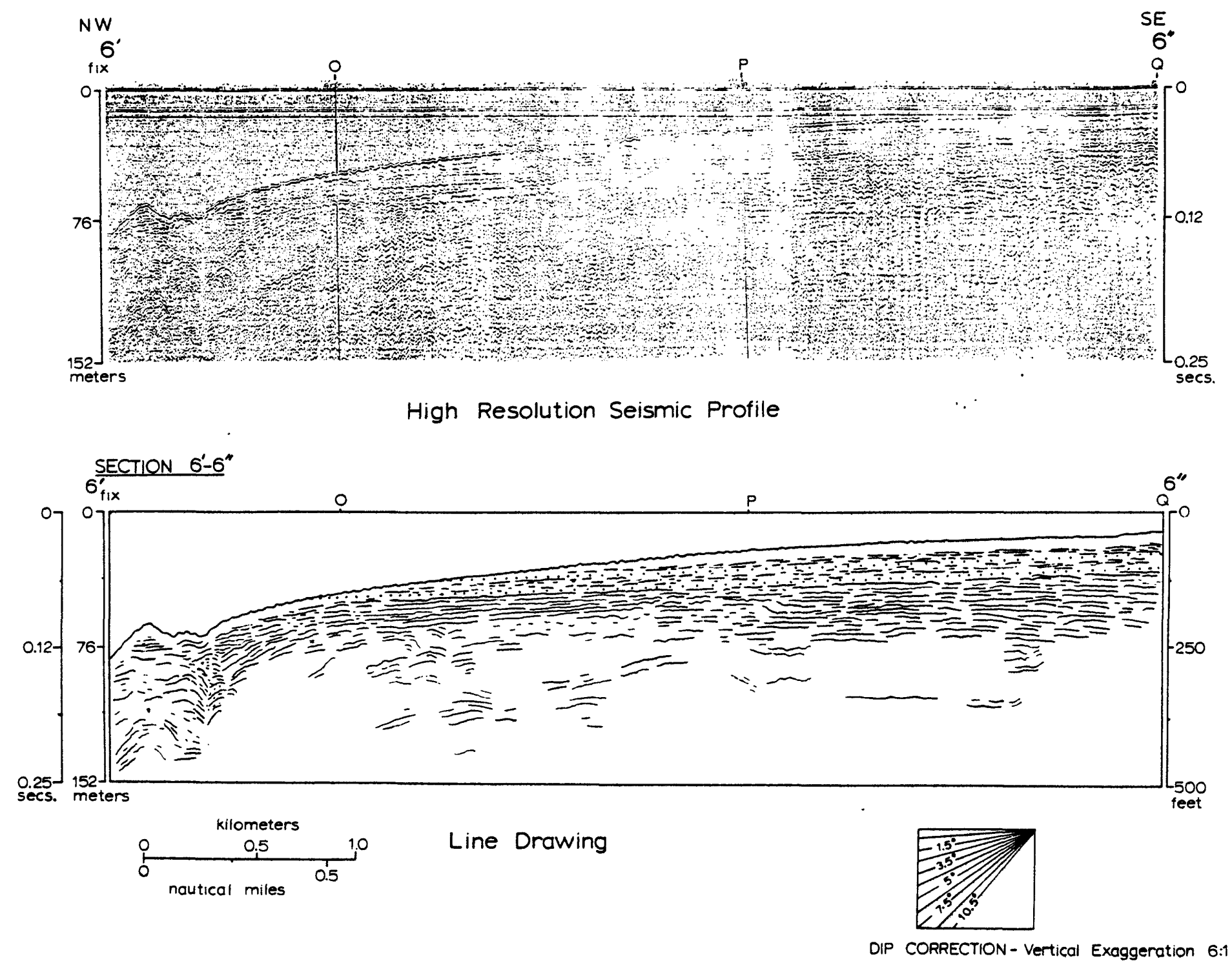
Figure 8. - High resolution seismic profile of Section $6^{\prime}-6^{\prime \prime}$ showing fresh water aquifer phantom horizons indicated by
dotted lines. 
Extrapolation of onshore geologic data, such as stratigraphic positions of the "180-foot" (55 meters) aquifer, were extended offshore as "phantom horizons" (Fig. 8). A "phantom horizon" is a line drawn from a known depth of a unit, parallel to structure (i.e., bedding planes, etc.) observed in the seismic profiles. 


\section{INTERPRETATION}

Structures and lithologic units that were interpreted from the seismic profiles have been used to construct a marine geologic map of the southern Monterey Bay region (Plate 1). The seismic criteria used to distinguish different units in the profiles is based on seismic signal characteristics and reflector types. For each unit discussed below the seismic criteria that was used to identify the unit is given in much the same way as lithologic criteria is given for distinguishing geologic units observed in outcrop on land.

Onshore well-hole data (Plate 1) was used to correlate the various known lithologic data in the lower Salinas Valley with the seismic units chosen on the profiles. Also, the stratigraphic positions of the "180-foot" (55 meters) aquifer known in the well holes onshore was extrapolated offshore and mapped as a member of the seismic unit that represents the Deltaic deposit. Geologic Map

Four major geologic units are identified from the seismic profiles (Fig. 9). These units consist of Mesozoic granodiorite, Miocene Monterey Formation, Pliocene to Pleistocene Paso Robles Formation and/or Aromas red sands unit, and Pleistocene to Holocene Deltaic deposits. Geologic structures observed in the profiles were mapped and give some new evidence for the understanding of submarine canyon processes and sea water intrusion of the ground water basin in Monterey Bay. Interpretations of the general limits 

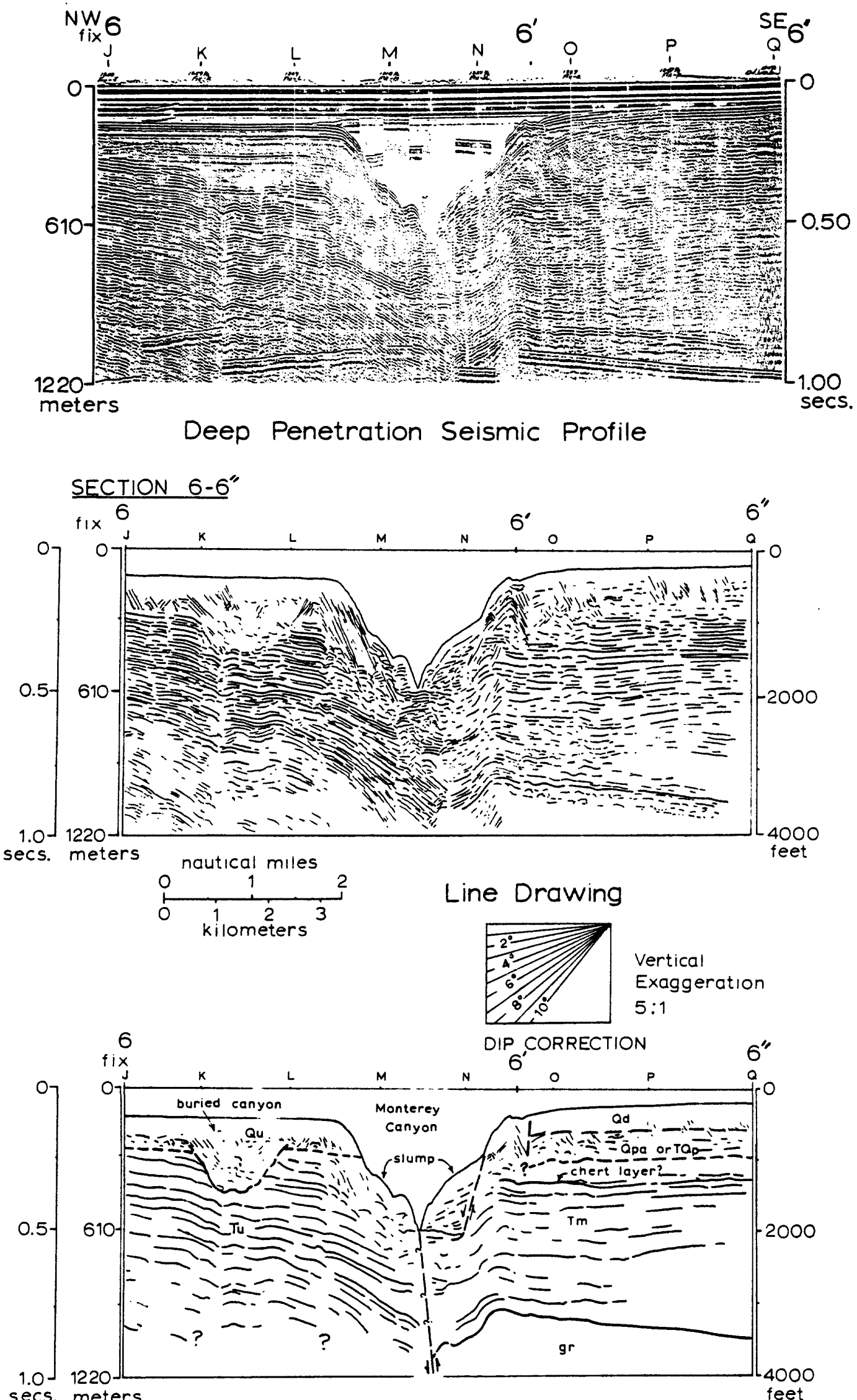

\section{Geologic Interpretation}

Figure 9.-- Line drawing and geologic interpretation of seismic profile $6-6$ ' showing all 4 lithologic units mapped in southern Monterey Bay. 
of the southern Monterey Bay ground water basin was made along with a rough approximation of the area where the "180-foot" (55 meters) aquifer might crop out on the floor of the bay.

\section{Mesozoic granodiorite}

Criteria used to identify the Mesozoic granodiorite in the seismic profiles consist of a very strongly reflected seismic signal with random noise, hyperbolic reflectors, and multiples returned from beneath the main reflector (Fig. 7). This type of criteria commonly represents acoustical basements that may consist of very well indurated sediments, metamorphic rocks, or crystalline rocks. Generally, the granitic surface is a very easily identifiable reflector that can be correlated from one track line to another with a minimum of difficulty.

The granodiorite is present at varying depths throughout the entire southern Monterey Bay area. Granitic rocks crop out on the bay bottom in the most southerly portion of Monterey Bay, around Point Pinos (Plate 1). They extend out from the point in a northeasterly, northerly, and northwesterly direction and remain at or near the surface for about. $2 \mathrm{~km}$ ( $1 \mathrm{mile}$ ) away from the point, at which place they gently dive at an average dip of $4^{\circ}$ to $4.5^{\circ}$ under the Miocene marine sediments. They reach an average maximum depth of 750 meters (2460 feet) under Monterey Submarine Canyon.

Several pipe dredge samples were taken in the area where the granodiorite crops out. These samples are similar to rocks exposed in the vicinity of the towns of Carmel and Monterey (Brabb, and Ross, written commun.). 


\section{Miocene Monterey Formation}

Criteria used to identify the Milocene marine sediments of the Monterey Formation consist of a strongly reflected seismic signal with very little random noise (Fig. 10). Many continuous reflectors with few discontinuous reflectors are observed in this unit. This type of criteria often represents fairly consolidated sediments that contain many beds of sands, silt, and clay. A very strong reflector is seen in the profiles about 100 meters ( 300 feet) beneath the estimated top of the Monterey Formation and is assumed to represent a relatively dense bed, probably of chert (Fig. 10). This reflector is everywhere continuous and is correlatable from one track line to another.

The marine strata of the Montery Formation generally has an average dip of $3^{\circ}$ to $4^{\circ}$ in a WNW direction, except in an area where it crops out on the bay floor and is complexly deformed; in a narrow band of about $20 \mathrm{~km}$ ( 6 naut. miles) 1ong by $6 \mathrm{~km}$ ( 1.5 naut. miles) wide and about $6 \mathrm{~km}$ ( 1.5 naut. miles) offshore of Point Pinos where it laps onto the granodiorite in the most southerly portion of the bay (Plate 1 and Fig. 11). In this area the Monterey Formation is about 275 meters (900-950) thick and is approximately 775 meters (2500-2600 feet) thick along the south wall of Monterey Submarine Canyon. It has an average thickness of 610 meters (200-2100 feet).

The Monterey Formation everywhere appears to overlie the Mesozoic granodiorite. The precise upper limit of the formation is more difficult to determine than the lower limit as the selsmic signal characteristics change gradually across the boundary rather than abruptly at the 


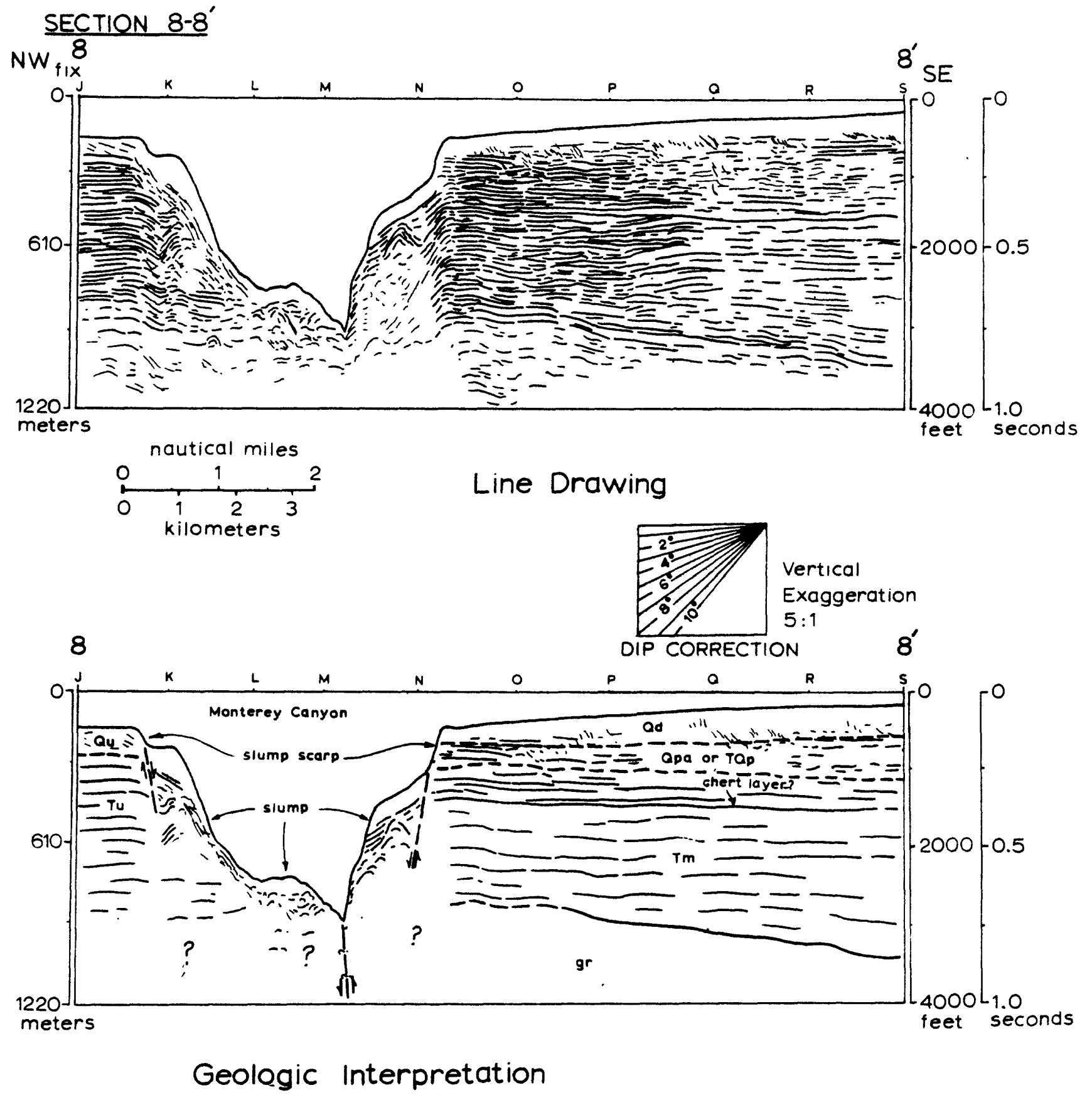

Figure 10-Line drawing and geologic interpretation of seismic profile $8-8^{\prime}$ showing Miocene marine strata with chert layer. 

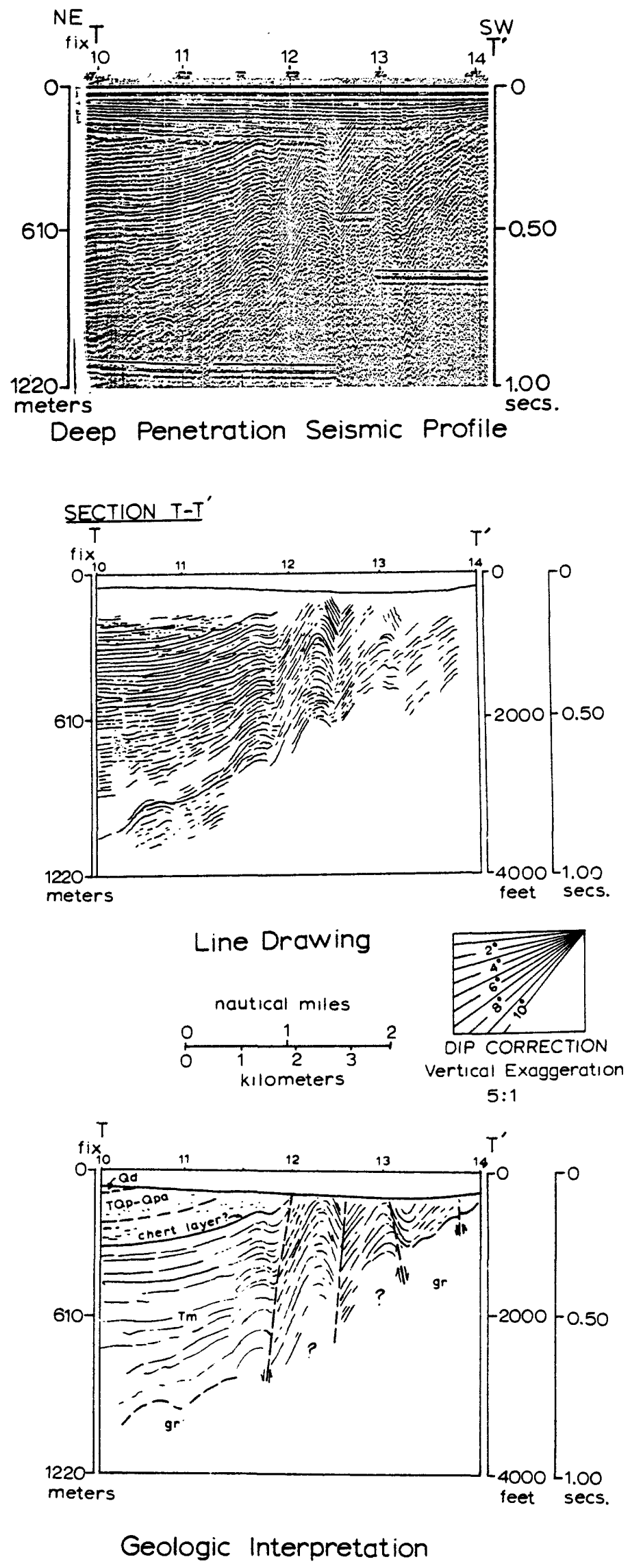

Figure 11.--Line drawing and geologic interpretation of sessmic profile $T-T^{\prime}$ showing complex folding and faulting in Monterey Formation. 
boundary. With the use of well-hole data onshore an estimated top of the Miocene was established, however, it is not possible to determine the type of contact that existsbetween the Miocene and the overlying Pliocene.

Dredge hauls made along the south wall of Monterey Submarine Canyon contain siltstone tentatively identified as Monterey. A complete analysis of these samples has not been done, therefore, sample description will have to wait until a later report is made.

Tertiary undifferentiated unit

The area mapped north of Monterey Submarine Canyon exhibit subsurface sedimentary units similar in seismic characteristics to the Monterey Formation. Criteria used to identify this unit consist of fairly strongly reflected seismic signal with very little random noise and exhibits many continuous reflectors. This type of criteria represents poorly indurated, fairly consolidated sand, silt, and clay (Plate 1 and Fig. 10).

Thickness of the Tertiary undifferentiated unit is unknown because the base of the unit is not observed in the seismic profiles. Structure is generally homoclinal in the mapped area.

Dredge hauls made along the north wall of Monterey Submarine Canyon contained siltstones and mudstones that have been assigned a tentative Tertiary age. It is belived that this unit is of Pliocene age and represents the Purisima Formation. However, since good evidence for the age of this unit is lacking it has been mapped as Tertiary undifferentiated. 


\section{Pliocene to Pleistocene Paso Robles Formation and/or Aromas Red}

\section{Sands Unit}

The criteria used to identify the Paso Robles Formation and/or Aromas red sands unit consist of a weakly reflected seismic signal with a large amount of random noise and noticeable absorption of seismic energy (Fig. 9 and 10). For the most part the reflectors are discontinuous or lacking all together. This type of criteria usually represents semi-consolidated to unconsolidated sedimentary material that is generally poorly sorted and consist mainly of sands and gravel. Since the lithologic materials representative of the Paso Robles Formation and the Aromas red sands produce similar seismic signal characteristics it is not possible to distinguish between the two in a seismic profile, therefore, they have both been included into one unit and are here after called the Paso Robles-Aromas unit.

The Paso Robles-Aromas unit overlies the Monterey Formation (Fig. 9 and 10). It is a relatively thin unit with a maximum thickness of 215 meters ( 700 feet) off the mouth of the Salinas River and an average of 150 meters ( $500 \mathrm{feet}$ ) for the overall thickness. The thickness of this unit is greatest nearshore and lenses into marine beds near its outer limits. It laps onto the northern edge of the band of complexly folded and faulted Monterey marine strata to the south and appears to crop out locally along portions of the south wall of Monterey Submarine Canyon. Because this unit appears to interfinger with the modern surficial sediments and its outer limit is difficult to determine in the seismic profiles, a best approximation for this outer limit was made. 
The Paso Robles-Aromas unit is overlain by the Deltaic deposit of Pleistocene to Holocene age. The contact between these two units is difficult to identify in the seismic profiles because, like the contact at the bottom of the Paso Robles-Aromas unit, there is a transitional change in seismic characteristics and is, therefore, not possible to determine whether this contact is depositional or erosional. Onshore well-hole data was used to establish the boundary between these two units.

\section{Pleistocene to Holocene Deltaic Deposits}

Criteria used to identify the Deltaic deposits consist of a very weakly reflected seismic signal with a very large amount of random noise and seismic energy absorption (Fig. 9 and 10). There are very few discontinuous reflectors and generally reflectors are lacking all together. This type of criteria commonly represents unconsolidated sediments consisting of gravels, sands, silts, and clays. The Deltaic deposit probably correlates with the Valleyfill materials found onshore.

The Deltaic deposit overlies the Paso Robles-Aromas unit. It ranges in thickness from zero to 85 meters (280 feet) and has an average thickness of 45 to 50 meters (150-160 feet). The maximum thickness of this unit is found just offshore and south of the Salinas River mouth and the thinnest portion of the unit is near or at its outer limit (Plate 1 and 2). Identification of the outer limit of the Paso Robles-Aromas unit, is very difficult and an 
approximation was made in order to establish the outer limit. The areal configuration of the Deltaic deposit is typical of deltas with a truncated apex near the Salinas River mouth and a fanning out of the deltaic material from the apex.

\section{Modern Surficial Sediments}

There is a thin veneer of modern sediments of an average thickness of 8 meters (25 feet) that appear to overlie most all units mapped in the bay. This veneer is very thin or lacking in the most southern portion of Monterey Bay and is thickest around the Salinas River delta. An accurate thickness of this Holocene material is not possible to determine because the seismic bubble pulse masks the area in which this unit appears.

\section{Quaternary Undifferentiated Unit}

Portions of the area mapped north of Monterey Submarine Canyon are covered with sediments similar in seismic characteristics to the Paso Robles-Aromas unit and the Deltaic deposits. Criteria used to identify this unit consist of a weakly reflected seismic signal with a large amount of random noise and noticeable absorption of seismic energy. This type of criteria represents poorly consolidated to unconsolidated gravels, sands, and silt.

Thickness of the Quaternary undifferentiated unit is variable and where present overlies the Tertiary undifferentiated unit (Plate 1 and Fig. 10). It is belived that this unit ranges in age from Pleistocene to Holocene. However, since good evidence for the age of this unit is lacking it is mapped as Quaternary undifferentiated. 


\section{Structure}

Structures observed in the seismic profiles consist of faults, folds, buried channels, slump features, and an unconformity. Most of the faults and folds mapped in the southern Monterey Bay are found in a relatively narrow band of Miocene marine strata of the Monterey Formation adjacent to the bottom contact of the Monterey Formation and the Mesozoic granodiorites (Plate 1). Other faults are randomly scattered throughout the area. The slump features are concentrated in Monterey Submarine Canyon.

1. Faults - The majority of the faults mapped in southern Monterey Bay have an average orientation of N50W. Most faults mapped are discontinuous or change in identifying characteristics between track 1ines, which makes correlation difficult or impossible. The highest density of faults, as well as the most continuous faults, are located in a zone within the narrow band of complexly disturbed Miocene strata (Plate 1). One of the two most continuous faults line up nicely with the onshore trend of the Tularcitos fault and because of this the fault zone is here called the Tularcitso fracture zone. The other continuous fault within the Tularcitos fracture zone exhibits a vertical displacement of both the Mesozoic granodiorites and the overlying Miocene marine strata of the Monterey Formation with the northern side down dropped. Not all faults within the Tularcitos fracture zone displace bedrock and not all of them displace the overlying beds of the Monterey Formation (Fig. 12). 


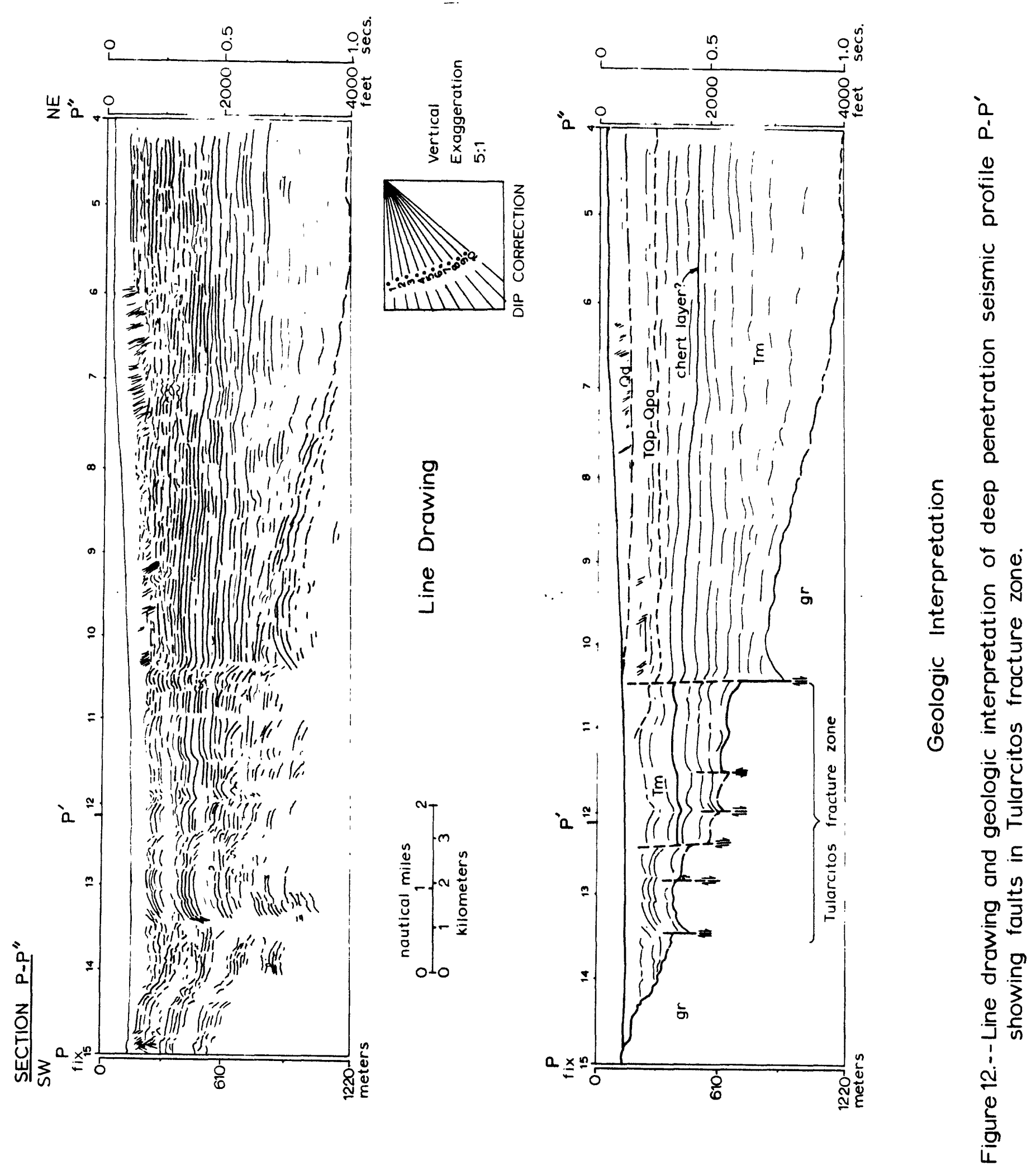


There are three other questionable and fairly continuous faults north of the Tularcitos fracture zone. These faults are mostly in the Paso Robles-Aromas unit and exhibit unknown amounts of vertical displacement. The two most northerly faults, if extended onshore, would line-up parallel to the inferred trend of the Gabilan fault (Plate 1); this, however, is a very weak correlation.

Another relatively major fault exists in the northern portion of the survey area. This fault generally trends in an east-west direction and exhibits a vertical sense of movement with the north side down dropped an unknown amount. It appears to be a tensional feature associated with the undercutting of the southern wall of Monterey Submarine Canyon. The fault is shallow and cuts through both the Paso Robles-Aromas unit and the overlying Deltaic deposit.

A questionable fault has been mapped along the axis of Monterey Submarine Canyon and is essentially an extension of Martin's (1967, p. 2286) Monterey Fault. The presence of this fault is inferred from the interpretations of the seismic profiles crossing the canyon axis. Seismic units identified in the profiles seem to end at the canyon and cannot, with any degree of confidence, be correlated from one side of the canyon to the other. Due to the complex side wall reflection effect created by the canyon, accurate identification and mapping of the fault is hampered. Since basement is lower on the north side of the fault than on the south, the fault is assumed to have a vertical displacement with the upthrown block to the south. 
2. Folds -- Generally, structure in the sedimentary units mapped in the southern Monterey Bay area is homoclinal except in the narrow band of complexly folded and faulted Miocene marine strata of the Tularcitos fracture zone (Plate 1 and Fig. 11). In this zone there are many continuous and discontinuous anticlines and synclines whose axes trend generally N50W. Most of the anticlines and synclines plunge toward the northwest, few plunge toward the southeast, and a few others are doubly plunging. The major continuous anticline and syncline in this area are located just north and south, respectively, of, and seem to be associated with, the Tularcitos fault and are here called the Tularcitos Anticline and the Tularcitos Syncline.

A syncline exists in the northwestern portion of both the Paso Robles-Aromas unit and the Deltaic deposit. This feature seems to be associated with a buried stream channel.

3. Buried Channel -- A large buried channel or buried canyon is present in the northern part of the survey area, north of the Monterey Submarine Canyon (Plate 1 and Fig. 9). This feature is approximately 230 meters ( 750 feet) deep and is filled and buried under about 53 meters (175 feet) of surficial material tentatively identified as Quaternary undifferentiated. It has been partly eroded and crops out on the northern wall of the present day submarine canyon.

4. Slump Features -- Many slump features have been identified in the seismic profiles and all are concentrated in Monterey Submarine Canyon (Plate 1, 4 and Fig. 13). Several stages 

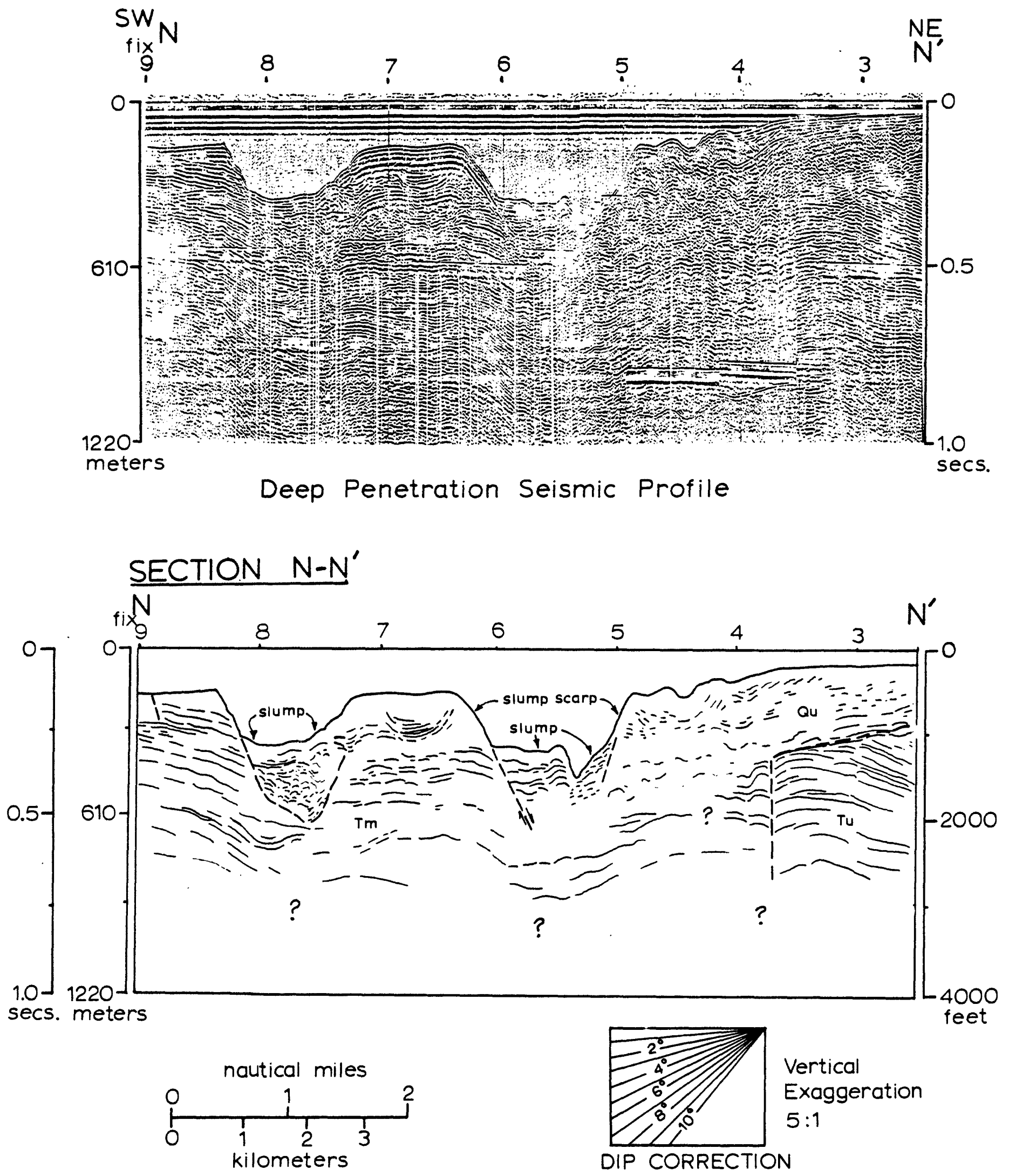

( Figure 13.-Deep penetration seismic profile of Section $N-N^{\prime}$ showing typical slump features characteristic of Monterey Canyon. 
of slump development are seen here with representation of geomorphic ages ranging from youthful to mature (Fig. 9 and 10). Generally, youthful slumps are characterized with flat tops, some showing backward rotation, and hummocky, distorted toes. Mature slumps are generally characterized by mostly hummocky topography at the base of steep slopes (Fig. 14).

One slump appears to be in the embryonic stage of formation and has been mapped as an "incipient slump" (Plate 1 and FIg. 14). A fault is seen at the top of the incipient slump and some wrinkling and folding can be seen along the area where the toe is expected to be found (Fig. 14).

Another slump consists of two distinct and different episodes of sliding (Plate 1, 4 and Fig. 14). One episode is classified as a youthful stage and the other, the upper, is classified as mature. This feature probably started as one large submarine slide and then sometime later during development the lower slump originated. Both the upper and lower slumps exhibit flat tops, but only the lower one shows a humnocky and distorted toe.

All the slump features mapped, except the incipient slump, have well developed headward scarps that are easily identifiable in the seismic profiles (Fig. 10 and 13). Several of these slumps are more than $4 \mathrm{~km}$ (2 miles) wide and have an average area of over $8 \mathrm{~km}^{2}$ (2 sq. naut. miles).

Some slumps on the north wall of Monterey Submarine Canyon appear to be locally cut into the buried channel or canyon fill and 


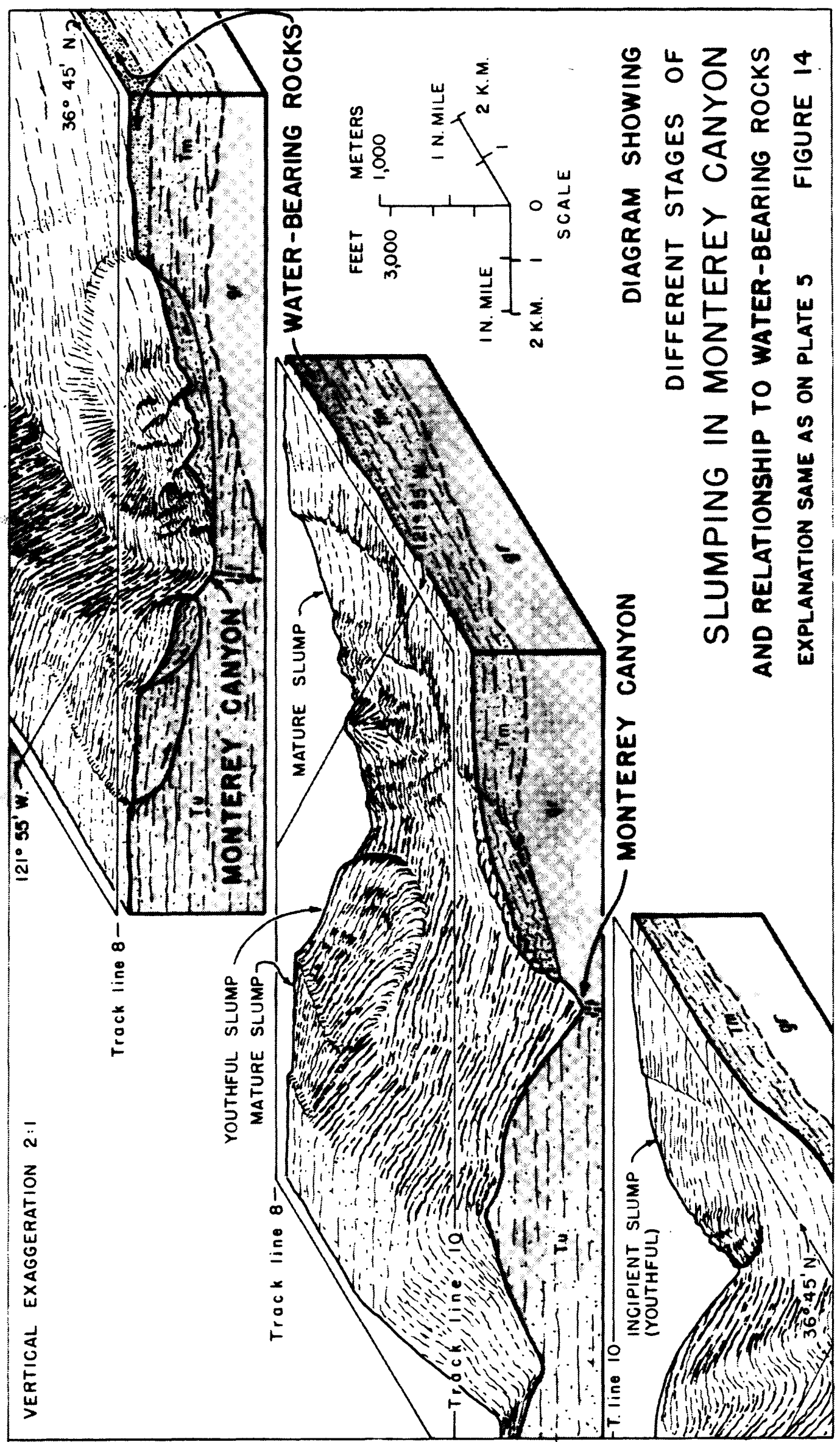


seem to have their development encouraged by the relatively unconsolidated and highly flowable nature of this material. The slumps on the south wall of Monterey Submarine Canyon seem to cut into semi-consolidated to unconsolidated material of the Paso RoblesAromas unit and the Deltaic deposit.

The large amount of slumping observed in the present day canyon indicates that undercutting and erosion has been active probably from the Pleistocene time and may still be active today in response to earlier and present undercutting. None of the profiles show complete damming of the canyon but some indicate that their toes have extended clear across the canyon axis and their V-shaped profiles suggest they had just recently been eroded.

5. Unconformity -- An unconformity has been mapped in the most southerly portion of Monterey Bay (Plate 1). This is an angular unconformity and seems to be a minor unconformity within the Miocene Monterey Formation, however, no age dates have yet been established.

\section{Isopach Maps}

Two isopach maps were constructed from data collected in southern Monterey Bay. Both maps were made in the area where the ground water basin is thought to exist. One isopach map is of the Deltaic deposit only (Plate 2) and the other is of both the Deltaic deposit and the underlying Paso Robles-Aromas unit (Plate 3) or the water-bearing sediment isopach map. 
The Deltaic deposit isopach map (Plate 2) is contoured at a 10 meter interval and shows an average sediment thickness of 45 to 50 meters (150-160 feet) and a maximum thickness of 85 meters (280 feet). The Deltaic deposits cover an area of $79 \mathrm{~km}^{2}(22-23$ sq. naut. miles) and contains the "180-foot" (55 meters) aquifer. The overall water-bearing sediment isopach map (Plate 3) is contoured at a 30 meter interval and shows an average sediment thickness of 200 meters (600-700 feet) and a maximum thickness of 300 meters (985 feet). These water-bearing sediments cover an area of $103 \mathrm{~km}^{2}$ (29-30 sq. naut. miles) and contain both the "180-foot" (55 meters) and "400-foot" (122 meters) aquifer. 


\section{SUMMARY AND CONCLUSIONS}

The geologic map shows that about half of southern Monterey Bay is underlain by water-bearing material while the other half is underlain by nonwater-bearing rocks. Mesozoic granodiorites and Miocene marine strata of the Monterey Formation outcrop on the bay floor in the most southerly portion of Monterey Bay. In this area the Monterey Formation is complexly folded and faulted whereas everywhere else it generally exhibits homoclinal structure. One possible reason for this isolated area of distorted marine sediments is its relationship with the Tularcitos fracture zone and its close proximity to the Mesozoic granodiorites. The Tularcitos fracture zone, possibly still active today, probably has created stress that is reflected in the folding and faulting of the fairly competent marine strata. Also, uplift of the nearby Mesozoic granodiorites which may still be going on, could have both tectonically and gravitationally disturbed the Monterey Formation in this area.

The water-bearing sediments of the Paso Robles-Aromas unit and the Deltaic deposit make-up the offshore ground water basin that contain the two main aquifers identified onshore. By extrapolating the "180-foot" aquifer offshore, an area of aquifer outcrop could be mapped (Plate 1 ). This area is approximate and is inferred to be an region of entrance of sea water into the aquifer. The Deltaic deposit, and thus the "180-foot" aquifer, does not everywhere extend to Monterey Canyon. Only the northern portion of this unit reaches the canyon and may outcrop on the canyon wall. However, there is a 
major fault just south of the canyon that cuts through the deltaic material; it is unknown whether this fault acts as an impermeable or permeable barrier. The remainder of the deltaic material feathers out on the ocean floor and the only points of salt water entrance lie away from the canyon.

The Paso Robles-Aromas unit is more extensive than the overlying Deltaic deposit and contains the "400-foot" aquifer. Northern portions of the Paso Robles-Aromas unit appear to outcrop on the southern wall of Monterey Submarine Canyon. The southern portion of this unit crops out on the ocean bottom in a relatively narrow zone between the bottom outcrops of the underlying Monterey Formation and the overlying Deltaic deposit. This zone is a possible entrance area for sea water, Also, the localities on the walls of Monterey Submarine Canyon where this unit crops out is an area where salt water encroachment can take place.

The northern part of the ground water basin, where it is in contact with the south wall of Monterey Submarine Canyon, is probably being actively eroded by slumping. Any preventive methods established in the lower Salinas Valley to retard salt water intrusion of the ground water basin must consider the slumping that is possibly active in the present day canyon offshore. The headward scarps of the slumps observed in the seismic profiles are generally young and probably represent new entrances for sea water intrusion, especially in 
localities where aquifers outcrop. New salt water intrusion entrances will continue to form as long as active slumping is taking place in the canyon.

The enigmatic gravels that Martin (1967) reported finding on the floor of the Monterey Submarine Canyon probably comes from the buried channel or canyon fill that is actively slumping away from the north wall of the modern day canyon. Other gravels may be derived from the Paso Robles-Aromas unit that outcrops locally on the southern wall of the canyon.

A physiographic diagram has been constructed by Mr. Tau Rho Alpha from both bathymetric and geologic data collected in Monterey Bay (Plate 5). This diagram vividly illustrates the location of the Deltaic deposit, and the ground water basin, and shows a fairly normal perspective of the slump features. 


\section{REFERENCES CITED}

Allen, J. E., 1946, Geology of the San Juan Bautista quadrangle, California: Calif. Div. Mines and Geology Bull. 133, 112 p.

Baldwin, T. A., 1963, Land forms of the Salinas Valley, California: in Guidebook to the Geology of the Salinas Valley and the San Andreas Fault; Pacific Sec., Am. Assoc. Petroleum Geologists Soc. Econ. Paleontologists and Mineralogists Annual Spring Field Trip, p. 11-13.

Bowin, 0. E., Geologic map of Monterey Quadrangle: Unpubl., Calif. Div. Mines and Geology.

Bramlette, M. N., 1946, The Monterey Formation of California and the origin of its siliceous rocks: U.S. Geological Survey Prof. Paper 212, p. 5 .

California State Department of Water Resources, 1958, Sea-water intrusion in California: Department of Water Resources Bull. 63, 91 p. California State Department of Water Resources, in press, Lower Salinas Valley Salt Water Intrusion Study.

Clark, B. L., 1930, Tectonics of the Coast Ranges of middle California: Geol. Soc. Amer. Bull., v. 41, p. 747-828.

Curray, J. R., 1966, Geologic Structure on the Continental Margin from subbottom profiles, Northern and Central California; in Geology of northern California: Calif. Div. Mines and Geology, Bull. 190, p. 337-342. 
Johnson, W. M., 1855, Extracts from a report on the features of the country between Pajaro and Salinas River, California: Ann. Rept. U.S. Coast Survey 1854, app. 22, p. 31-32.

Manning, J. C., 1963, Resume of ground water hydrology in Salinas Valley, California; in Guidebook of the Geology of the Salinas Valley and the San Andreas Fault; Pacific Sec. Am. Assoc. Petroleum Geologists - Soc. Econ. Paleontologists and Minera1ogists Annual Spring Field Trip, p. 106-109.

Martin, B. D., 1964, Monterey submarine canyon, California: Genesis and relationship to continental geology: unpubl. Ph.D. dissert., Univ. Southern California., 249 p.

Martin, B. D., and Emery, K. O., 1967, Geology of Monterey Canyon, California: Am. Assoc. Petroleum Geologists Bull. v. 51, p. 2281-2304.

Rusnak, G. A., 1967, High-efficiency subbottom profiling: U.S. Geol. Survey Prof. Paper 575-C, p. C81-C91.

Shepard, F. P., 1948, Investigation of the head of Monterey Submarine Canyon: Scripps Inst. Oceanography, Submarine Geology Rept. 1, $15 \mathrm{p}$.

Starke, G. W., and Howarả, A. D., 1968, Polygenetic Origin of Monterey Submarine Canyon: Geol. Soc. America Bull., v. 79, p. 813-826. Taliaferro, N. L., 1943, Geologic history and structure of the central Coast Ranges of California: Calif. Div. Mines and Geology Bull. 118, p. 119-163. 
Woodford, A. 0., 1951, Stream gradients and Monterey sea valley:

Am. Geol. Soc. Bull. v. 62, p. 799-852.

Woodring, W. P., 1938, Pliocene and Pleistocene deformation in the

California Coast Ranges: Geol. Soc. Am. Bul1., Proc. for 1937,

v. 49, p. 212 (abs.). 


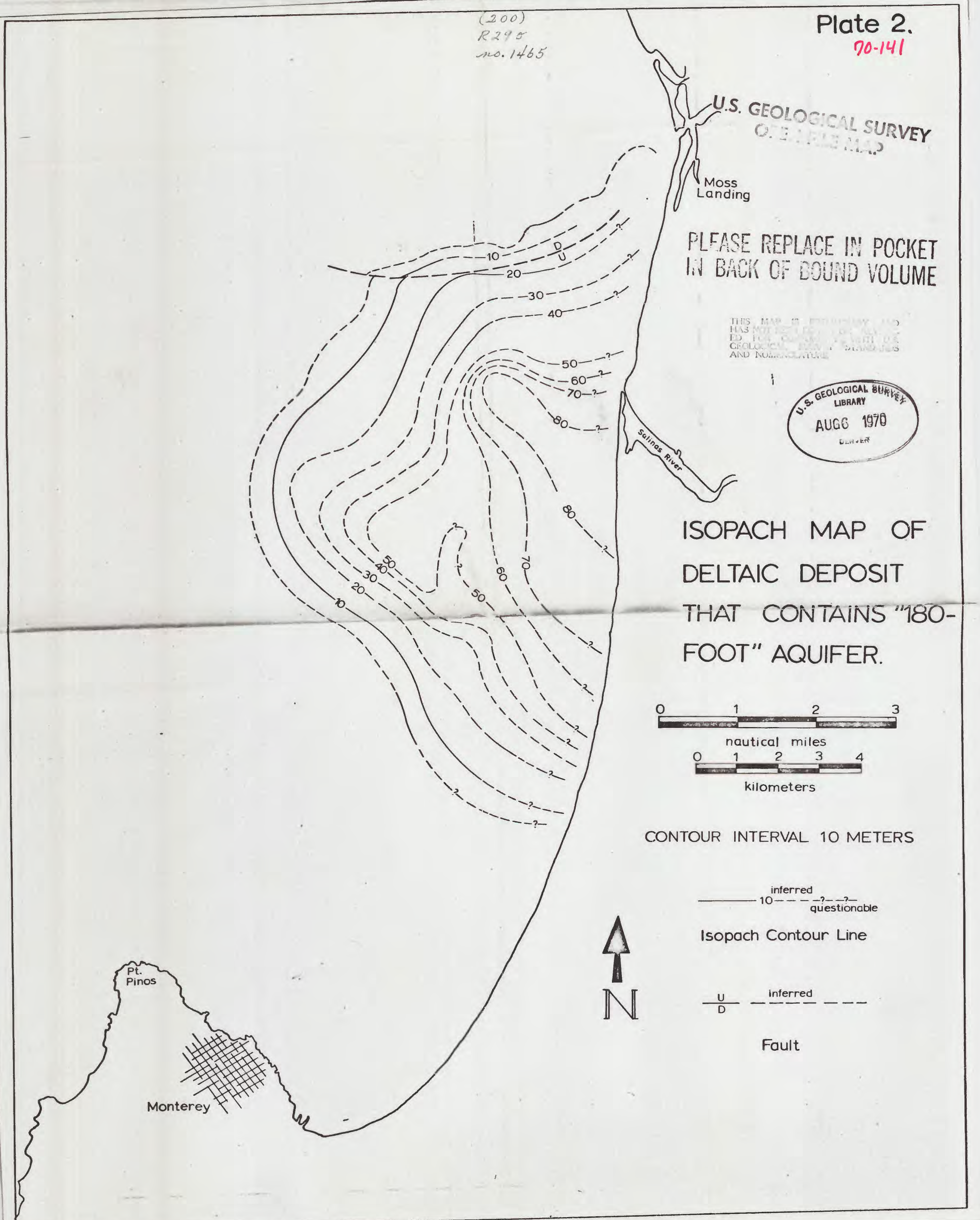

